\title{
O CANDOMBLÉ E O TEMPO Concepções de tempo, saber e autoridade da África para as religiões afro-brasileiras*
}

\section{Reginaldo Prandi}

I

Diferentes sociedades e culturas têm concepções próprias do tempo, do transcurso da vida, dos fatos acontecidos e da história. Em sociedades de cultura mítica, também chamadas sem-história, que não conhecem a escrita, o tempo é circular e se acredita que a vida é uma eterna repetição do que já aconteceu num passado remoto narrado pelo mito. As religiões afro-brasileiras, constituídas a partir de tradições africanas trazidas pelos escravos, cultivam até hoje uma noção de tempo que é muito diferente do "nosso" tempo, o tempo do Ocidente e do capitalismo (Fabian, 1985). A

* Conferência apresentada no evento "Tempo Inoculado", no Centro Cultural Banco do Brasil, no Rio de Janeiro, em 31 de janeiro de 2001. Agradeço a Marcello Dantas, curador do evento, pelo entusiasmo, e a Teresinha Bernardo, pelas sugestões amigas e competentes. noção de tempo, por se ligar à noção de vida e morte e às concepções sobre o mundo em que vivemos e o outro mundo, é essencial na constituição da religião.

Muitos dos conceitos básicos que dão sustentação à organização da religião dos orixás em termos de autoridade religiosa e hierarquia sacerdotal dependem do conceito de experiência de vida, aprendizado e saber, intimamente decorrentes da noção de tempo ou a ela associados. Assim, muitos aspectos das religiões afro-brasileiras podem ser melhor compreendidos quando se consideram as noções básicas de origem africana que os fundamentam. Da mesma maneira se pode ampliar o conhecimento sobre valores e modos de agir observáveis entre os seguidores dessas religiões quando consideramos a herança africana original em oposição a concepções ocidentais com que a religião africana teve e tem de se confrontar no Brasil, sobretudo nas situações em que concepções de diferentes origens culturais se 
opõem e provocam ou propiciam mudanças naquilo que os próprios religiosos acreditam ser a tradição afro-brasileira, seja ela doutrinária, seja ritual. As noções de tempo, saber, aprendizagem e autoridade, que são as bases do poder sacerdotal no candomblé, de caráter iniciático, podem ser lidas em uma mesma chave, capaz de dar conta das contradições em que uma religião que é parte constitutiva de uma cultura mítica, isto é a-histórica, se envolve ao se reconstituir como religião numa sociedade de cultura predominantemente ocidental, na América, onde tempo e saber têm outros significados.

O candomblé de que trata o presente texto é a religião dos orixás formada na Bahia, no século XIX, a partir de tradições de povos iorubás, ou nagôs, com influências de costumes trazidos por grupos fons, aqui denominados jejes, e residualmente por grupos africanos minoritários. O candomblé iorubá, ou jeje-nagô, como costuma ser designado, congregou, desde o início, aspectos culturais originários de diferentes cidades iorubanas, originando-se aqui diferentes ritos, ou nações de candomblé, predominando em cada nação tradições da cidades ou região que acabou lhe emprestando o nome: queto, ijexá, efã (Silveira, 2000; Lima, 1984). Esse candomblé baiano, que proliferou por todo o Brasil, tem sua contrapartida em Pernambuco, onde é denominado xangô, sendo a nação egba sua principal manifestação, e no Rio Grande do Sul, onde é chamado batuque, com sua nação oió-ijexá (Prandi, 1991). Outra variante iorubá, esta fortemente influenciada pela religião dos voduns daomeanos, é o tambor-demina nagô do Maranhão. Além dos candomblés iorubás, há os de origem banta, especialmente os denominados candomblés angola e congo, e aqueles de origem marcadamente fom, como o jeje-mahim baiano e o jeje-daomeano do tamborde-mina maranhense.

Foram principalmente os candomblés baianos das nações queto (iorubá) e angola (banto) que mais se propagaram pelo Brasil, podendo hoje ser encontrados em toda parte. O primeiro veio a se constituir numa espécie de modelo para o conjunto das religiões dos orixás, e seus ritos, panteão e mitologia são hoje praticamente predo- minantes. O candomblé angola, embora tenha adotado os orixás, que são divindades nagôs, e absorvido muito das concepções e ritos de origem iorubá, desempenhou papel fundamental na constituição da umbanda, no início do século XX, no Rio de Janeiro e em São Paulo. Hoje, todas essas religiões e nações congregam adeptos que seguem ritos distintos, mas que se identificam, nos mais diversos pontos do país, como pertencentes a uma mesma população religiosa, o chamado povo-de-santo, que compartilha crenças, práticas rituais e visões de mundo, que incluem concepções da vida e da morte. Terreiros localizados nas mais diferentes regiões e cidades interligam-se através de teias de linhagens, origens e influências que remetem a ascendências que convergem, na maioria dos casos para a Bahia, e que daí apontam, no caso das nações iorubás, para antigas e, às vezes, lendárias cidades hoje situadas na Nigéria e no Benim.

A idéia que norteia o presente trabalho é refazer inicialmente essa trajetória, religando a África dos orixás aos terreiros de candomblé de nações iorubás, que podem hoje ser encontrados na Bahia, no Rio de Janeiro, em São Paulo, no Distrito Federal e outros Estados, para, num segundo momento, procurar entender como e por quê as antigas heranças religiosas vão sofrendo mudanças e adaptações no contexto das transformações socioculturais que modelam o Brasil atual. Embora o texto presente esteja focado na observação do candomblé iorubá, para o qual podemos contar com uma etnografia que permite estabelecer comparações entre o que se observou na África e o que se observa no Brasil, é fato que muitas das conclusões podem ser, em maior ou menor grau, aproximadas para o conjunto das religiões afrobrasileiras, quando não extravasadas para além do universo estritamente religioso, em outras dimensões da cultura popular brasileira.

\section{II}

Um novo adepto do candomblé ou outra religião afro-brasileira tradicional que tenha nascido e sido criado fora dessa religião, na qual ele in- 
gressa por escolha pessoal, não é caso raro (Prandi, 2000a). Desde que o candomblé se transformou numa religião aberta a todos, independentemente da origem racial, étnica, geográfica ou de classe social, grande parte dos seguidores, ou a maior parte em muitas regiões do Brasil, é de adesão recente, não tendo tido anteriormente, nem mesmo no âmbito familiar, maior contato com valores e modos de agir característicos dessa religião. Na maioria dos casos, aderir a uma religião também significa mudar muitas concepções sobre o mundo, a vida, a morte. O novo adepto do candomblé, ao freqüentar o terreiro, o templo, e participar das inúmeras atividades coletivas indispensáveis ao culto, logo se depara com uma nova maneira de considerar o tempo. Ele terá que ser ressocializado para poder conviver com coisas que, nos primeiros contatos, lhe parecerão estranhas e desconfortáveis. Ele tem de aprender que tudo tem sua hora, mas que essa hora não é simplesmente determinada pelo relógio e sim pelo cumprimento de determinadas tarefas, que podem ser completadas antes ou depois de outras, dependendo de certas ocorrências, entre as quais algumas imprevisíveis, o que pode adiantar ou atrasar toda a cadeia de atividades. Aliás, esses termos "atrasar" e "adiantar" são estranhos à situação que desejo considerar, pois no candomblé, como já disse, tudo tem seu tempo, e cada atividade se cumpre no tempo que for necessário. É a atividade que define o tempo e não o contrário.

As festas de candomblé, quando são realizadas as celebrações públicas de canto e dança, as chamadas cerimônias de barracão, durante as quais os orixás se manifestam por meio do transe ritual, são precedidas de uma série de ritos propiciatórios, que envolvem sacrifício de animais, preparo das carnes para o posterior banquete comunitário, fazimento das comidas rituais oferecidas aos orixás que estão sendo celebrados, cuidado com os membros da comunidade que estão recolhidos na clausura para o cumprimento de obrigações iniciáticas, preparação da festa pública e finalmente a realização da festa propriamente dita, ou seja, o chamado toque. Preparar o toque inclui cuidar das roupas, algumas costuradas especialmente para aquele dia, que devem ser lavadas, engomadas e passadas a ferro (é sempre uma enormidade de roupas para engomar e passar!); pôr em ordem os adereços, que devem ser limpos e polidos; preparar as comidas que serão servidas a todos os presentes e providenciar as bebidas; decorar o barracão, colhendo-se para isso as folhas e flores apropriadas etc. etc.

Num terreiro de candomblé, praticamente todos os membros da casa participam dos preparativos, sendo que muitos desempenham tarefas específicas de seus postos sacerdotais. Todos comem no terreiro, ali se banham e se vestem. Às vezes, dorme-se no terreiros noites seguidas, muitas mulheres fazendo-se acompanhar de filhos pequenos. É uma enormidade de coisas a fazer e de gente as fazendo. Há uma pauta a ser cumprida e horários mais ou menos previstos para cada atividade, como "ao nascer do sol", "depois do almoço", "de tarde", "quando o sol esfriar", "de tardinha", "de noite". Não é costume fazer referência e nem respeitar a hora marcada pelo relógio e muitos imprevistos podem acontecer. No terreiro, aliás, é comum tirar o relógio do pulso, pois não tem utilidade. Durante a matança, os orixás são consultados por meio do jogo oracular para se saber se estão satisfeitos com as oferendas, e podem pedir mais. De repente, então, é preciso parar tudo e sair para providenciar mais um cabrito, mais galinhas, mais frutas, ou seja lá o que for. Em qualquer dos momentos, orixás podem ser manifestar e será preciso cantar para eles, se não dançar com eles. Os orixás em transe podem, inclusive, impor alterações no ritual. Eles podem ficar muitas horas "em terra" enquanto todos os presentes lhes dão atenção e tudo o mais espera. Durante o toque, a grande cerimônia pública, a presença não prevista de orixás em transe implica o alargamento do tempo cerimonial, uma vez que eles devem também ser vestidos e devem dançar. A chegada de dignitários de outros terreiros, com seus séquitos, obriga a homenagens adicionais e outras seqüências de canto e dança. Embora haja um roteiro mínimo, a festa não tem hora para acabar. Não se sabe exatamente o que vai acontecer no minuto seguinte, o planejamento é inviabilizado pela intervenção dos deuses.

Quando se vai ao terreiro, é aconselhável não marcar nenhum outro compromisso fora dali 
para o mesmo dia, pois não se sabe quando se pode ir embora, não se sabe quanto tempo vai durar a visita, a obrigação, a festa. Aliás, candomblé também não tem hora certa para começar. Começa quando tudo estiver "pronto". Os convidados e simpatizantes vão chegando num horário mais ou menos previsto, mas podem esperar horas sentados. Então muitos preferem chegar bem tarde, o que pode acarretar novos atrasos. E não adianta reclamar, pois logo alguém dirá que "candomblé não tem hora". Uma vez, depois de muita espera, perguntei a que horas iria o candomblé realmente começar. A resposta foi: "Depois que mãezinha (a mãe-de-santo) trocar de roupa.” Enfim, o tempo será sempre definido pela conclusão das tarefas consideradas necessárias no entender do grupo, a fórmula: "quando estiver pronto".

Essa idéia de que o tempo está sujeito ao acontecer dos eventos e ao sabor da realização de tarefas necessárias pode ser observada no cotidiano dos terreiros também fora das festas. Pesquisadores que estão se iniciando em trabalho de campo se espantam muito com a "falta de horário" das mães e pais-de-santo, tendo que esperar horas e horas, se não dias, para fazer uma entrevista que pensavam estar agendada para um horário bem determinado. Clientes que vão ao terreiro para o jogo de búzios ou outros serviços mágicos também podem se sentir incomodados pelo modo como o povo-de-santo usufrui do tempo.

Em 1938, a antropóloga americana Ruth Landes veio ao Brasil para estudar as relações raciais entre nós e permaneceu vários meses em pesquisa junto aos candomblés de Salvador. É muito interessante o relato de seu primeiro encontro com a jovem Mãe Menininha do Gantois, que décadas depois viria a ser a mais famosa mãe-de-santo do Brasil. Marcada a visita, Menininha a recebeu e com ela começou a conversar com muita simpatia. Chegou então uma filha-de-santo que cumprimentou a mãe com todas as reverências, dizendolhe alguma coisa em voz baixa. Menininha pediu licença à antropóloga para se retirar um momento, dizendo-lhe que ficasse à vontade e que voltaria em seguida. A tarde se esvaiu, com muita movimentação na casa, muitas pessoas chegando e saindo, mas a mãe-de-santo não voltou à sala.
Com o dia já escuro, discretamente, Ruth Landes voltou para seu hotel. Só tempos depois pôde continuar sua conversa com a ialorixá. Soube mais tarde a antropóloga que a mulher que interrompera a entrevista trazia problemas e que a mãe fora cuidar dos rituais necessários para resolver a aflição da filha (Landes, 1967: 86-99). Comentando o episódio, Ruth Landes escreveu: "Durante a minha permanência na Bahia pasmava-me a liberdade que as mães tomavam com o tempo. Menininha não voltou à sala aquele dia e como soube, subseqüentemente, sempre se atrasava, sempre demorava. Era um privilégio da sua posição, aceito como natural numa terra de aristocracia e escravidão. Que era o tempo? O tempo era o que se faz com ele e ela estava sempre ocupada" (Landes, 1967, p. 95). O que Landes atribuiu a privilégios numa terra de aristocracia e escravidão era, entretanto, a expressão de uma concepção africana de tempo muito diferente daquela a que estamos habituados por força de nossa cultura européia.

Para o pensador africano John Mbiti, enquanto nas sociedades ocidentais o tempo pode ser concebido como algo a ser consumido, podendo ser vendido e comprado como se fosse mercadoria ou serviço potenciais - tempo é dinheiro -, nas sociedades africanas tradicionais o tempo tem que ser criado ou produzido. Mbiti afirma que "o homem africano não é escravo do tempo, mas, em vez disso, ele faz tanto tempo quanto queira". Comenta que, por não conhecerem essa concepção, muitos estrangeiros ocidentais não raro julgam que os africanos estão sempre atrasados naquilo que fazem, enquanto outros dizem: "Ah! Esses africanos ficam aí sentados desperdiçando seu tempo na ociosidade" (Mbiti, 1990, p. 19).

\section{III}

Antes da imposição do calendário europeu, os iorubás, que são a fonte principal da matriz cultural do candomblé brasileiro (Prandi, 2000b), organizavam o presente numa semana de quatro dias. O ano era demarcado pela repetição das estações e eles não conheciam sua divisão em meses. A duração de cada período de tempo era mar- 
cada por eventos experimentados e reconhecidos por toda a comunidade. Assim, um dia começava com o nascer do sol, não importando se às cinco ou às sete horas, em nossa contagem ocidental, e terminava quando as pessoas se recolhiam para dormir (Mbiti, 1990, p. 19), o que podia ser às oito da noite ou à meia-noite em nosso horário. Essas variações, importantes para nós, com nosso relógio que controla o dia, não o eram para eles.

Cada um dos quatro dias da semana iorubá tradicional, chamada ossé, é dedicado a uma divindade (Ojô Awô, Ojô Ogum, Ojô Xangô, Ojô Obatalá, respectivamente, dia do segredo ou de Ifá, dia de Ogum etc.), regulando uma atividade essencial para a vida de todos os iorubás tradicionais: o mercado. O mercado ou feira funciona em cada aldeia e cidade num dos dias da semana, todas as semanas ou a cada duas, três ou quatro semanas. Até hoje, as mulheres vão vender seus produtos nos mercados de diferentes cidades, fazendo dessa atividade uma instituição fundamental para a sociabilidade iorubá e a regulação do cotidiano. Os iorubás tradicionais reconheciam a existência do mês lunar, mas lhe davam pouca importância, sendo muito mais importantes as épocas de realização das grandes festas religiosas, marcadas pelas estações e fases agrícolas do ano, que eles chamavam de odum. O dia era dividido não em horas, mas em períodos, que poderíamos traduzir por expressões como "de manhã cedo", "antes do sol a pino", "com o sol na vertical", "de tardinha" etc. A noite era marcada pelo cantar do galo.

A contagem dos dias e das semanas era praticada em função de cada evento, de modo que a mulher era capaz de controlar a duração de sua gestação, assim como o homem contava o desenrolar dos seus cultivos, mas sem datação (Ellis, 1974, pp. 142-151). Os iorubás tradicionais consideravam duas grandes estações, uma chuvosa e outra seca, separadas por uma estação de fortes ventos, de modo que cada ano podia durar alguns dias a mais ou a menos, dependendo do atraso ou adiantamento das estações, mas isso não importava, uma vez que os dias não eram contados. Os anos passavam como passavam as semanas e os dias, num fruir repetitivo, não se computando aritmeticamente cada repetição.
Nas cortes dos reis iorubás havia funcionários encarregados de manter viva a memória dos reis, e eles eram treinados para recitar os eventos importantes que marcaram o reinado de cada soberano, mas os episódios não eram datados, fazendo com que a reconstrução recente da história dos povos iorubás não comportasse uma cronologia para os tempos anteriores à chegada dos europeus, vendose obrigada a operar com mitos e memórias lançados num passado sem datas (Johnson, 1921).

Como o tempo é cíclico, fatos inesperados são recebidos com espanto. Assim, as ocorrências cíclicas da natureza - por exemplo, as fases da lua e as estações climáticas - são encaradas como acontecimentos normais da vida, mas o que escapa do ritmo normal do tempo é visto com preocupação e medo, como um eclipse, uma enchente etc. O nascimento de gêmeos, que contraria o desenlace normal da gestação, constitui também um fato excepcional.

Os afro-descendentes assimilaram o calendário e a contagem de tempo usados na sociedade brasileira, mas muitas reminiscências da concepção africana podem ser encontradas no cotidiano dos candomblés. A chegada de um novo odum, ano novo, é festejada com ritos oraculares para se saber qual orixá o preside, pois cada ano vê repetir-se a saga do orixá que o comanda: será um ano de guerra, se o orixá for um guerreiro, como Ogum, de fartura, se o orixá for um provedor, como Oxóssi, será de reconciliações, se for de um orixá da temperança, como Iemanjá, e assim por diante. O ossé, a semana, constituiu-se num rito semanal de limpeza e troca das águas dos altares dos orixás. Cada dia da semana, agora a semana de sete dias, é dedicado a um ou mais orixás, sendo cada dia propício a eventos narrados pelos mitos daqueles orixás, por exemplo, a quarta-feira é dia de justiça porque é dia de Xangô. As grandes festas dos deuses africanos adaptaram-se ao calendário festivo do catolicismo por força do sincretismo que, até bem pouco tempo, era praticamente compulsório, mas o que a festa do terreiro enfatiza é o mito africano, do orixá, e não o do santo católico.

Embora o candomblé e outras religiões de origem africana sejam de formação recente, aqui 
constituídas somente depois das primeiras décadas do século XIX, as datas de fundação dos terreiros, assim como as que marcam os reinados de sucessivas mães e pais-de-santo no início, são desconhecidas. Seus nomes são bem lembrados e seus feitos são cantados e festejados nas cerimônias que louvam os antigos fundadores - o padê nos candomblés mais velhos -, mas nada de datas. Esse passado brasileiro também já se fez mito.

\section{IV}

Nas palavras de Wole Soyinka, "o pensamento tradicional opera não uma sucessão linear de tempo mas uma realidade cíclica" (Soyinka, 1995, p. 10). O tempo escalar, que se mede matematicamente, podendo ser somado, subtraído, dividido etc., não faz nenhum sentido para o pensamento africano tradicional. Para os ocidentais, o tempo é uma variável contínua, uma dimensão que tem realidade própria, independente dos fatos, de tal modo que são os fatos que se justapõem à escala do tempo. É o tempo da precisão, que objetiva o cálculo, que viabiliza a projeção e fundamenta a racionalidade - tempo da ciência histórica e da modernidade. Nessa escala ocidental do tempo, os acontecimentos são enfileirados uns após outros, em seqüências que permitem organizá-los como anteriores e posteriores, uns como causa e outros como conseqüência, construindo-se uma cadeia de correlações e causações que conhecemos como história. Entre nós, o relógio e o calendário permitem contar o tempo transcorrido entre dois eventos, sendo possível, mesmo num passado distante, saber que fatos estão mais próximos entre si e quais mais se distanciam. Um segmento de tempo pode ser comparado com outro, por exemplo, o tempo médio da vida de um homem. Assim, todos os fatos relevantes são datados, isto é, descritos num calendário seqüencial escalonado em intervalos iguais (século, ano, mês, dia, hora). Esse tempo é projetado para a frente, de modo que o que vai acontecer compõe com o presente e com o já acontecido uma linha sem solução de continuidade, estando o futuro deter- minado pelo que o precede, podendo assim ser controlado pela ação no presente.

Para os africanos tradicionais, o tempo é uma composição dos eventos que já aconteceram ou que estão para acontecer imediatamente. É a reunião daquilo que já experimentamos como realizado, sendo que o passado, imediato, está intimamente ligado ao presente, do qual é parte, enquanto o futuro nada mais é que a continuação daquilo que já começou a acontecer no presente, não fazendo nenhum sentido a idéia do futuro como acontecimento remoto desligado de nossa realidade imediata (Mbiti, 1990, pp. 16-17). O futuro que se expressa na repetição cíclica dos fatos da natureza, como as estações, as colheitas vindouras, o envelhecer de cada um, é repetição do que já se conheceu, viveu e experimentou, não é futuro. Não há sucessão de fatos encadeados no passado distante, nem projeção do futuro. A idéia de história como a conhecemos no Ocidente não existe; a idéia de fazer planos para o futuro, de planejar os acontecimentos vindouros, é completamente estapafúrdia. Se o futuro é aquilo que não foi experimentado, ele não faz sentido nem pode ser controlado, pois o tempo é o tempo vivido, o tempo acumulado, o tempo acontecido. Mais que isso, o futuro é o simples retorno do passado ao presente, logo, não existe.

Para os iorubás e outros povos africanos, antes do contato com a cultura européia, os acontecimentos do passado estão vivos nos mitos, que falam de grandes acontecimentos, atos heróicos, descobertas e toda sorte de eventos dos quais a vida presente seria a continuação. Ao contrário da narrativa histórica, os mitos nem são datados nem mostram coerência entre si, não existindo nenhuma possibilidade de julgar se um mito é mais verossímil, digamos, do que outro. Cada mito atende a uma necessidade de explicação tópica e justifica fatos e crenças que compõem a existência de quem o cultiva, o que não impede de haver versões conflitantes quando os fatos e interesses a justificar são diferentes. O mito fala do passado remoto que explica a vida no presente. O tempo mítico é apenas o passado distante, e fatos separados por um intervalo de tempo muito grande podem ser apresentados nos mitos como ocorrên- 
cias de uma mesma época, concomitantes. Cada mito é autônomo e os personagens de um podem aparecer em outro, com outras características e relações, às vezes, contraditórias, sem que isso implique algum tipo de questionamento da sua veracidade. Os mitos são narrativas parciais e sua reunião não propicia o desenho de qualquer totalidade. Não existe um fio narrativo na mitologia, como aquele que norteia a construção da história para os ocidentais. O tempo do mito é o tempo das origens, e parece existir um tempo vazio entre o fato contado pelo mito e o tempo do narrador. No mundo mítico, os eventos não se ajustam a um tempo contínuo e linear. A mitologia dos orixás, que fala da criação do mundo e da ação dos deuses na vida cotidiana, bem o demonstra (Prandi, 2001).

Esse passado remoto, de narrativa mítica, é coletivo e fala do povo como um todo. Passado de geração a geração, por meio da oralidade, é ele que dá o sentido geral da vida para todos e fornece a identidade grupal e os valores e normas essenciais para a ação naquela sociedade, confundindo-se plenamente com a religião. O tempo cíclico é o tempo da natureza, o tempo reversível, e também o tempo da memória, que não se perde, mas se repõe. O tempo da história, em contrapartida, é o tempo irreversível, um tempo que não se liga nem à eternidade, nem ao eterno retorno (Prigogine, 1991: 59). O tempo do mito e o tempo da memória descrevem um mesmo movimento de reposição: sai do presente, vai para o passado e volta ao presente - não há futuro. A religião é a ritualização dessa memória, desse tempo cíclico, ou seja, a representação no presente, através de símbolos e encenações ritualizadas, desse passado que garante a identidade do grupo - quem somos, de onde viemos, para onde vamos? É o tempo da tradição, da não-mudança, tempo da religião, a religião como fonte de identidade que reitera no cotidiano a memória ancestral. No candomblé, emblematicamente, quando o filho-de-santo entra em transe e incorpora um orixá, assumindo sua identidade representada pela dança característica que lembra as aventuras míticas dessa divindade, é o passado remoto, coletivo, que aflora no presente para se mostrar vivo, o transe ritual repetindo o passado no presente, numa representação em carne e osso da memória coletiva.

\section{$\mathbf{V}$}

Como parte da vida que transcorre no presente, e numa dimensão diferente daquela do passado mítico, existe um passado próximo formado pelos eventos que compõem a vivência particular do indivíduo e que depende de sua memória pessoal. Os mortos, por exemplo, enquanto são lembrados pelos parentes vivos, fazem parte desse passado recente que se confunde com o presente e, assim, participam da experiência presente dos vivos enquanto estiverem vivos na lembrança dos vivos. Continuam a fazer parte da família, sendo por ela louvados e alimentados, até que um dia possam retornar reencarnados. Com a reencarnação tudo se repete, o ciclo se recompõe. Assim como se repetem as estações do ano, as fases da lua, os ciclos reprodutivos, o desenrolar das semeaduras às colheitas, a vida do homem se repete na reencarnação: cíclica é a natureza, cíclica é a vida do homem, cíclico é o tempo.

Para os iorubás tudo acontece em três planos: o $A i \hat{e}$, que é este nosso mundo, o do tempo presente; o Orum, que é o outro mundo, a morada dos deuses orixás e dos antepassados, o mundo mítico do passado remoto; e o mundo intermediário dos que estão aguardando para renascer. Este mundo dos que vão nascer está próximo do mundo aqui-e-agora, o Aiê, e representa o futuro imediato, atado ao presente pelo fato de que aquele que vai nascer de novo continua vivo na memória de seus descendentes, participando de suas vidas e sendo por eles alimentados, até o dia de seu renascimento como um novo membro de sua própria família. Para o homem, o mundo das realizações, da felicidade, da plenitude é o mundo do presente, o Aiê (Babatunde, 1992, p. 33). Não há prêmio nem punição no mundo dos que vão nascer, nada ali acontece. Os homens e mulheres pagam por seus crimes em vida e são punidos pelas instâncias humanas. As punições impostas aos humanos pelos deuses e antepassados por causa 
de atos maus igualmente não os atingem após a morte, mas se aplicam a toda coletividade à qual o infrator pertence, e isso também acontece no Aiê. Trata-se de uma concepção ética focada na coletividade e não no indivíduo (Mbon, 1991, p. 102), não existindo a noção ocidental cristã de salvação no outro mundo nem a de pecado. O outro mundo habitado pelos mortos é temporário, transitório, voltado para o presente dos humanos. Nem a vida espiritual tem expressão no futuro.

É preciso que o morto não tenha sido esquecido pelos seus familiares para poder nascer de novo, pois seu lugar é sempre na família. São duas as condições para se continuar vivo na memória, no presente. Primeiro, é preciso ter tido muitos filhos, pois um homem sem prole não tem quem cultive sua memória. Um homem sem prole não tem uma grande família onde ele possa renascer. Para tanto é necessário ter muitas mulheres e poder sustentá-las. Segundo, deve ter vivido muito, para que seus atos memoráveis tenham sido testemunhados pelos filhos, netos e, quem sabe, bisnetos. Muitos nomes iorubás dados a uma nova criança referem-se àquele de quem ela se acredita ser simplesmente o retorno, como Babatundê, que quer dizer o pai está de volta; Iyabó, a mãe retorna; Babatunji, o pai acordou de novo. A memória depende da convivência, e é graças a ela que se conhece, ama e respeita o outro. A lembrança é um sentimento de veneração respeitosa e afetiva. Para renascer, então, tem que se viver até uma idade provecta. Ai dos que morrem cedo, estes terão dificuldade para renascer. Quando se morre na tenra infância pode-se renascer como outra criança gerada no útero da mesma mãe (Oduyoye, 1996, p. 113). Contudo, este não é um nascimento festejado, pelo contrário, é temido, pois a criança renascida não tem compromisso com o presente, com a família, com o Aiê, e pode perfeitamente querer morrer de novo cedo, sem viver, pelo simples e degenerado prazer de nascer por nascer. Essas criaturas, chamadas abicus, literalmente, nascido para morrer, só fazem sofrer as mães e frustrar os pais, que precisam desesperadamente de uma longa descendência, pois os filhos que geram filhos são a garantia da eternidade celebrada no presente.
Quando a memória do morto extravasa os limites de sua família particular e passa a ser louvada pela comunidade mais ampla da aldeia, da cidade, de uma grande linhagem que reúne muitas famílias, quando esta lembrança deixa de ser privativa de alguns indivíduos para se incorporar na lembrança coletiva, o morto não precisa mais renascer entre os vivos para garantir o ciclo de sua eternidade. Ele vai para o Orum, tornando-se, então, um antepassado. Isso acontece com os grandes reis, heróis, fundadores e líderes. Do Orum, o mundo mítico onde habita com os deuses orixás, ele passa a atuar diretamente nos acontecimentos do $A i \hat{e}:$ vai interferir no presente, ajudando e punindo os humanos. O passado mítico é um passado vivo, e seus habitantes o tempo todo agem e interferem no presente. Os antepassados, que os iorubás chamam de egunguns, não se recusam a vir ao Aiê e conviver com os humanos e o fazem através de seus sacerdotes nos grandes festivais de máscaras em que se cultua a memória ancestral coletiva daquela comunidade (Drewal, 1992, cap. 6).

Quando, numa outra dimensão, o antepassado conquista o respeito de todo um povo, quando sua cidade impõe seu culto a outras, quando ele se desprende da comunidade original e passa a fazer parte da memória de toda uma sociedade, a reverência por ele recebida se expande, sua influência no Aiê cresce, seu poder no mundo do presente se eterniza: ele é, então, um orixá, um entre os deuses iorubás. Sua relação não é mais com os parentes nem com os membros da sua comunidade, mas com a humanidade. Ele pode até mesmo ser reverenciado em terras do além-mar, onde se fará atuante no presente de muitos outros povos, como ocorreu com a diáspora iorubá na América por força da escravidão, com a fundação de novos cultos e religiões, como o candomblé, o tambor-de-mina, o xangô e o batuque, no Brasil, e a santeria, em Cuba. Ele é parte do passado mítico, e o passado mítico responde pelo presente. O passado mítico é o que existe desde o começo dos tempos, o que sempre foi, o que não é datado.

Os iorubás acreditam que o espírito do ser humano é constituído de diversas partes imateriais, sua alma não é indivisível como na concepção ju- 
daico-cristã. Há uma individualidade espiritual chamada ori que só existe no presente, isto é, enquanto se vive no Aiê. Ela é responsável pelas realizações humanas, contém o destino de cada pessoa. O ori morre e é destruído juntamente com o corpo material. Outra parte é constituída da memória cultuada pela família do morto, o egum, que volta ao presente por meio da reencarnação, que mantém o morto no presente. E, como parte fundamental, talvez a mais importante, há o orixá particular da pessoa, considerado o seu antepassado remoto. O orixá particular da pessoa é uma ínfima porção do orixá geral cultuado por todos. É o vínculo do ser humano com o divino, o eterno, o passado mítico. Com a morte do corpo, o orixá pessoal retorna ao orixá geral, àquele que existe desde o princípio dos tempos. O ori representa o presente do ser humano; o egum, a sua capacidade de retornar sempre a esse presente, ou se eternizar no Orum como antepassado egungum; o orixá pessoal, a ligação do presente com o mito, com o passado remoto que age sobre o presente e do qual recebe as honrarias sacrificiais. O passado reproduzido no presente pela infinidade de humanos, nos quais os orixás se perpetuam a cada nascimento, pois cada ser humano descende de um orixá, fecha de novo o ciclo africano do tempo.

A escravidão destruiu as estruturas familiares dos africanos trazidos como escravos para a América, submeteu-os a um ritmo de trabalhado compulsório e alienado, impôs novas crenças e um novo modo de vida cotidiana que pressupunha uma outra maneira de contar o tempo e de o conceber. Assim, quando a religião dos orixás foi reconstruída entre nós, muitos dos aspectos e conceitos da antiga cultura africana deixaram de fazer sentido e muitos desapareceram. Mas muito das velhas idéias e noções se reproduziram na cultura religiosa dos terreiros de candomblé e de outras religiões dedicadas aos orixás iorubanos, voduns fons e inquices bantos, assim como muita coisa se conservou, em maior ou menor escala, em aspectos não religiosos da cultura popular de influência africana.

No Brasil dos dias de hoje, o candomblé continua a cultuar a memória de seus mortos ilustres, invocados em diferentes cerimônias e relem- brados de geração a geração, mas não pôde preservar a idéia de que os mortos renascem na família carnal, pois a adesão ao candomblé é individual e a família-de-santo não corresponde necessariamente à família biológica. A idéia do antepassado egungum veio ocupar um lugar secundário na religião, apenas complementar na religião dos orixás, que na maioria dos terreiros de formação recente é praticada sem essa referência. Como a religião dos orixás congrega grupos minoritários, cada um pertencente a um determinado terreiro, autônomo em relação aos demais, grupos formados por adeptos que fazem parte de uma sociedade mais ampla, cuja cultura é predominantemente ocidental e cristã, o culto a antepassados coletivos que controlam a moralidade de uma cidade inteira, digamos, como ocorria originalmente em terras africanas, não se viabilizou por razões evidentes. O mundo brasileiro fora dos muros do terreiro não é território dos antepassados, como era na África tradicional.

A concepção iorubá de reencarnação sofreu na América a influência da idéia cármica de reencarnação do espiritismo kardecista - religião de origem européia que prega a reencarnação como mecanismo de um sistema ético de premiação e punição dos atos praticados em vida e que permite ao espírito do morto aperfeiçoar-se através de muitas vidas (Prandi, 2000c). O kardecismo tem uma concepção de tempo repetitivo em espiral, que expressa mudança, evolução espiritual, aperfeiçoamento voltado para o futuro neste e no outro mundo, tudo muito diferente da visão africana.

Além da influência kardecista, as concepções africanas da morte também foram se borrando no contato da religião dos orixás com as noções próprias do catolicismo hegemônico, durante mais de um século de sincretismo. O rito funerário do axe$x \hat{e}$ (Prandi, 1999), celebrado para desligar o morto da vida presente, para que ele possa partir e depois voltar como outra pessoa, rito que representa a quebra de todos os vínculos do morto com o Aiê, continua a ser praticado, mas tende hoje a ser realizado com mais freqüência nas exéquias dos líderes mais expressivos do terreiro de candomblé. Raramente se realiza quando o morto ocupa um lugar inferior na hierarquia religiosa. 
Justifica-se hoje mais pela etiqueta da corte do que pela concepção tradicional de reencarnação. Não parece, contudo, que os seguidores do candomblé e de outras religiões afro-brasileiras tenham incorporado decisivamente nem a noção de carma do espiritismo nem a idéia salvacionista cristã de julgamento, prêmio e punição após a morte, de tal modo que o futuro que se descortina depois desta vida, segundo a concepção cristã, continua a ser para os religiosos brasileiros afrodescendentes, pelo menos em certa medida, um tempo desprovido de sentido: depois da morte, o que se esperaria, assim, é voltar para este mundo, para o presente do Aiê.

\section{VI}

Para os iorubás o tempo é cíclico, tudo o que acontece é repetição, nada é novidade. Aquilo que nos acontece hoje e que está prestes a acontecer no futuro imediato já foi experimentado antes por outro ser humano, por um antepassado, pelos próprios orixás. O oráculo iorubano, praticado pelos babalaôs, que são os sacerdotes de Ifá ou Orunmilá, o deus da adivinhação, baseia-se no conhecimento de um grande repertório de mitos que falam de toda sorte de fatos acontecidos no passado remoto e que voltam a acontecer, envolvendo personagens do presente. É sempre o passado que lança luz sobre o presente e o futuro imediato.

Conhecer o passado é deter as fórmulas de controle dos acontecimentos da vida dos viventes. Esse passado mítico, que se refaz a cada instante no presente, é narrado pelos odus do oráculo de Ifá. Cada odu é um conjunto de mitos, cabendo ao babalaô descobrir qual deles conta a história que está acontecendo ou que vai acontecer na vida presente do consulente que o procura em busca de solução para suas aflições. Quando o adivinho identifica o mito que se relaciona com o presente do consulente, e o faz usando seus apetrechos mágicos de adivinhação, fica sabendo quais procedimentos rituais - como sacrifícios, recolhimento e purificações - devem ser usados para sanar os males que afligem o cliente. A fór- mula receitada é a mesma aplicada no passado, quando foi usada com sucesso, conforme narra o mito. Nada é novo, tudo se refaz. Também é atribuição do babalaô identificar, no nascimento de uma criança, a reencarnação de um ente querido. Não se pode dar nome a uma criança sem antes saber de onde ela vem, pois um nascimento não é uma tábula rasa. É um retorno. O babalaô é ao mesmo tempo o guardião do passado e o decifrador do presente. Ele usa o passado para a decifração do presente. Seu demorado e penoso treinamento o obriga a aprender de cor milhares de versos, os poemas de Ifá, que narram o passado mítico de seu povo, seus deuses e seus heróis (Prandi, 1996, cap. 3).

Não há mais babalaôs no Brasil, mas os pais e mães-de-santo operam as antigas técnicas oraculares. Não aprendem os poemas de Ifá, atribuição dos antigos babalaôs, mas sua magia ainda consiste em descobrir o odu que rege cada situação presente, como meio de desvendar no presente as mesmas causas dos acontecimentos no passado. E saná-las, com o mesmo receituário.

\section{VII}

À concepção africana de tempo no candomblé e em outras denominações religiosas de origem negro-africana estão intimamente associadas as idéias de aprendizado, saber e competência. Para os africanos tradicionais, o conhecimento humano é entendido, sobretudo, como resultado do transcorrer inexorável da vida, do fruir do tempo, do construir da biografia. Sabe-se mais por que se é velho, porque se viveu o tempo necessário da aprendizagem. A aprendizagem não é uma esfera isolada da vida, como a nossa escola, mas um processo que se realiza a partir de dentro, participativamente. Aprende-se à medida que se faz, que se vive. Com o passar do tempo, os mais velhos vão acumulando um conhecimento a que $o$ jovem só terá acesso quando tiver passado pelas mesmas experiências. Mesmo quando se trata de conhecimento especializado, o aprendizado é por imitação e repetição. As diferentes confrarias profissionais, especialmente as de caráter mágico e 
religioso, dividem as responsabilidades de acordo com a senioridade de seus membros e estabelecem ritos de passagem que marcam a superação de uma etapa de aprendizado para ingresso em outra, que, certamente, implica o acesso a novos conhecimentos, segredos ou mistérios da confraria. A importância dos ritos de passagem foi enfaticamente preservada nas religiões afro-brasileiras; ritos que são sua marca mais notável. Na carreira iniciática, cada etapa corresponde, evidentemente, ao compromisso de novas obrigações e ao alcance de novos privilégios. A passagem de uma etapa para outra não é determinada pelo tempo escalar, nem poderia, mas por aquilo que realmente o iniciado é capaz de fazer. Mais uma vez, o que conta é a experiência. Ser mais velho é saber certo, fazer mais e melhor. Muitas das diferentes atribuições profissionais, talvez as mais importantes, são herdadas, passadas de pai para filho, de mãe para filha, numa clara reafirmação de que a vida é repetição.

Os iorubás só conheceram a escrita com a chegada dos europeus. Assim, todo o conhecimento tradicional baseia-se na oralidade. Mitos, fórmulas rituais, louvações, genealogias, provérbios, receitas medicinais, encantamentos, classificações botânicas e zoológicas, tudo é memorizado. Tudo se aprende por repetição, e a figura do mestre acompanha por muito tempo a vida dos aprendizes. Os velhos são os depositários da cultura viva do povo e a convivência com eles é a única maneira de aprender o que eles sabem. Os velhos são os sábios e a vida comunitária depende decisivamente de seu saber, de seus mistérios. $\mathrm{O}$ ancião detém o segredo da tradição. Sua palavra é sagrada, pois é a única fonte de verdade.

Essa forma de conceber o aprendizado e o saber entra em crise nos candomblés quando seus membros, já escolarizados, passam a se valer das fórmulas escritas que, pouco a pouco, vão surgindo disponíveis nos livros e em outras publicações. Mais que isso, os seguidores das religiões dos orixás, voduns e inquices são, hoje em dia, provenientes das mais diferentes origens e classes sociais e todos eles, ou sua grande maioria, conhecem a experiência efetiva de se aprender na escola. Esta é orientada para a efetivação do aprendizado rápido, racional e impessoal, o saber premido pelo tempo de calendário. A escola, mecanismo de transmissão de todo o saber considerado importante pela sociedade, é uma instituição para jovens. Em nossa sociedade, é na juventude que se domina o conhecimento e espera-se que os jovens saibam mais do que os velhos. De fato, um jovem de vinte anos, hoje, pode saber mais do que seus pais e muito mais do que seus avós, porque aprende na escola, onde o conhecimento avança rapidamente. O saber está fora de casa, fora da família. E o conhecimento nunca é definitivo, pois está em permanente expansão e constante reformulação, devendo cada um atualizar-se, tomar ciência das novas descobertas que surgem sem cessar.

Em nossa sociedade, a velhice é concebida como a idade da estagnação, do atraso, da aposentadoria, que significa etmologicamente recolhimento aos aposentos e conseqüente abandono da vida produtiva e pública. O jovem não aprende mais convivendo com os mais velhos, aprende com a leitura e as instituições da palavra escrita, e não há professor sem livro. O conhecimento através da escrita, cujo acesso se amplia com a aquisição de livros, com as consultas às bibliotecas, e agora com a chamada navegação na internet, não tem limites, e muito menos segredo. Tudo está ao alcance dos olhos e nem é preciso esperar. Etapas do aprendizado podem ser queimadas, nada pode deter a vontade de saber.

Essa nova maneira de conceber o aprendizado, a idade e o tempo interfere muito nas noções de autoridade religiosa, hierarquia e poder religioso, dando lugar a contradições e conflitos no interior do candomblé, questionando a legitimidade do poder dos mais velhos, provocando mudanças no processo de iniciação sacerdotal.

\section{VIII}

Ainda hoje nos candomblés do Brasil procura-se ensinar que a experiência é a chave do Conhecimento, que tudo se aprende fazendo, vendo, participando. Cada coisa no seu devido tempo. Assim, o conhecimento do velho é o conhecimen- 
to legítimo, ao qual se chega ao longo de toda uma vida. Roger Bastide, que estudou o candomblé na década de 50 , escreveu que "são os sacerdotes que têm a noção do valor do tempo; é o tempo que amadurece o conhecimento das coisas; o ocidental tudo quer saber desde o primeiro instante, eis por que, no fundo, nada compreende" (Bastide, 1978, p. 12).

Toda a hierarquia religiosa é montada sobre o tempo de aprendizagem iniciática, numa lógica segundo a qual quem é mais velho viveu mais e, por conseguinte, sabe mais. Mas para o jovem de mentalidade ocidental, o tempo urge, o tempo deve ser vencido. A palavra escrita é o meio de acesso ao saber e a oralidade não faz mais nenhum sentido. Só faz sentido quando se acredita que a fórmula aprendida pela via da oralidade é a única capaz de se mostrar eficaz, mas isso é uma imposição religiosa defendida apenas pelos amantes da tradição, seja lá o que isso possa significar. Numa sociedade como a nossa, em que a ciência já desmascarou o segredo, é difícil acreditar que tudo tem o seu tempo, e que é preciso esperar a hora certa, pois a vida diária e a luta pela sobrevivência se encarregam de mostrar o contrário. Em nossa cultura, é premiado quem chega primeiro.

Os membros de um candomblé são classificados basicamente em duas grandes categorias de idade iniciática: os iaôs, aqueles iniciados há pouco tempo e que formam o grupo júnior, e os ebômis, os iniciados há bastante tempo e que assim são capazes de realizar, com autonomia, atividades rituais mais complexas, o grupo sênior. A palavra ebômi, do iorubá egbomi, significa exatamente "meu mais velho", e era assim que na antiga família poligínica iorubá as esposas mais velhas se tratavam. Iaô, nessa família tradicional, era a denominação dada às esposas mais novas. No candomblé, enquanto os ebômis conquistam certa autonomia em relação à autoridade suprema da mãe ou do pai-de-santo e são encarregados de tarefas rituais importantes, de prestígio dentro do grupo, com privilégios e honras especiais, as iaôs (ou os iaôs, pois há muito a palavra iâ̂ perdeu no candomblé a conotação de esposa), os jovens iniciados, enfim, só fazem obedecer, usando símbolos e cultivando gestos e posturas que denotam a sua inferioridade hierárquica. Lembrando que a estrutura organizacional do candomblé é uma reprodução simbólica da estrutura tradicional da família iorubá, de resto perdida no Brasil, evidenciase a importância da experiência acumulada na constituição dos grupos de autoridade. Os ebômis são os que sabem, porque são mais velhos, viveram mais, acumularam maior experiência. Sua autoridade é dada pelo tempo acumulado, que pressupõe saber maior.

Como o candomblé é religião e em nossa sociedade a religião é uma das esferas autônomas da cultura (o que faz da religião dos orixás na América algo bem diferente do que foi na África), a noção de tempo acumulado no âmbito religioso entre nós tende a ser, e cada vez é mais, descolada do tempo que marca o transcurso da vida. Pode-se ingressar no candomblé, por livre escolha, em qualquer momento da vida, em qualquer idade. Assim, a idade biológica da pessoa não é a mesma da idade iniciática, de modo que um jovem iniciado há muito tempo pode ser o ebômi de um iâ̂ que se iniciou depois de maduro. O tempo de iniciação transformou-se no tempo que realmente conta. Evidentemente, nos primórdios do candomblé, a passagem de uma sacerdotisa júnior para a categoria sênior era o resultado natural do saber religioso acumulado durante o tempo necessário, durasse quanto durasse. O reconhecimento por parte do grupo de sua capacidade e competência na realização de atribuições rituais complexas era resultado natural do fazer dessas atribuições, combinado com a dedicação religiosa expressa por meio de sucessivas obrigações rituais a que se submetia a devota. Cuidar de seu orixá pessoal, oferecendo-lhe os necessários sacrifícios periódicos, e trabalhar com autonomia em benefício do grupo eram as condições que indicavam maturidade, competência nos ritos, capacidade de liderança, saber e autoridade.

Numa determinada época da consolidação do candomblé, foi necessária a criação de rito de passagem específico que tornasse público o reconhecimento da condição de senioridade, rito hoje conhecido pelo nome de decá, a partir do qual a iaô assume a posição de ebômi, de mais velho. Agora fazendo parte de uma sociedade em que o 
tempo que conta é o tempo do calendário, dotado em nossa cultura de objetividade inquestionável, o candomblé acabou por mensurar em anos o tempo de aprendizagem do iaô. Depois de se submeter ao grande rito de passagem que o inclui no candomblé como sacerdote júnior, a chamada feitura de orixá, o iaô pode, depois de anos de aprendizado, e tendo cumprido os ritos intermediários, ascender ao grau de ebômi, conquistando assim sua senioridade. Como sênior poderá receber incumbências de mando, assumir tarefas de prestígio e iniciar novos adeptos, podendo, se quiser, abrir seu próprio terreiro. Em algum momento no meio do curso do século XX - e ninguém sabe dizer como foi nem de onde veio a iniciativa -, a lei-do-santo, espécie de código consensual não escrito que regula os costumes e a vida religiosa nos terreiros, em permanente constituição, fixou em sete o número mínimo de anos necessários ao recebimento do grau de senioridade, o tempo do decá, tempo de autoridade. O decá é o coroamento de uma seqüência de obrigações que inclui, depois da feitura, a obrigação de um ano, a de três anos e finalmente a de sete anos, tudo definido numa escala de tempo ocidental. Evidentemente, atrasos eventuais em qualquer etapa arrastam para adiante o período total.

O tempo de iniciação, agora computado em termos de anos, meses e dias, e em certos casos horas, impõe-se como chave do ordenamento hierárquico no grupo, instituindo-se o que os antropólogos chamam de peking order, a "ordem das bicadas", uma disposição hierárquica que pode ser observada nos galinheiros. Ali, uma galinha, certamente a mais forte, a líder inconteste, bica todas as demais e não é bicada por nenhuma; uma segunda é bicada pela primeira e bica as outras; uma terceira é bicada por essas duas e bica as demais, e assim por diante, até a última galinha, que é bicada por todas e não bica nenhuma. Esse esquema, muito característico de sociedades de estruturação social mais simples e de associações iniciáticas, é rigorosamente observado nos candomblés. Pode ser apreciado na ordem em que as filhas-de-santo se colocam na roda das danças, na ordem dos pedidos de bênção - quem beija a mão de quem - e em quase todos os momentos em que a etiqueta do terreiro imprime a marca do tempo.

Um lema da chamada lei-do-santo muito cultivado afirma que o mais velho sabe mais e que sua verdade é incontestável. Saber é poder, é proximidade maior com os deuses e seus mistérios, é sabedoria no trato das coisas de axé, a força mística que move o mundo, manipulada pelos ritos. Por isso, o mais novo prostra-se diante do mais velho e lhe pede a bênção, não lhe dirige a palavra se não for perguntado, pede licença - Agô ebômi, licença meu mais velho - para falar na sua presença, oferece-lhe sua comida antes de começar a comer - Ajeum, vamos comer, servido? -, abaixa a cabeça quando dele se aproxima, curvase à sua passagem, inclina-se e o cumprimenta juntando as mãos - Mojubá, salve! - quando se canta para o orixá a que este mais velho é devotado. Tudo isso acontece numa ordem na qual cada um conhece bem o seu posto, ou pelo menos deveria conhecer.

Contudo, no mundo em que vivem, os jovens aprendem que idade não é sinônimo de sabedoria. No candomblé, experimentam que nem sempre os mais velhos em iniciação sabem mais. O jovem aprende no terreiro, mas pode ampliar seus conhecimentos religiosos por meio de outras fontes, sendo que a leitura pode ser uma porta aberta que o leva a um universo de informação sobre as coisas da religião do qual o mais velho nem suspeita. O jovem perde a confiança no mais velho, contesta sua sabedoria, rompe sua lealdade para com aqueles que o iniciaram e pode abandonar o grupo à procura de outros líderes que lhe pareçam mais apropriados, mudando de axé, como se diz, mudando de terreiro, de família-desanto, de filiação religiosa. Muitos que se iniciam hoje no candomblé têm uma aspiração ocupacional muito clara: desejam ser pais e mães-de-santo, buscando nessa religião, como acontece nas outras, um meio de vida e uma oportunidade de ascensão social. Para esses, quanto mais cedo for alcançada a senioridade, melhor, não raro burlando a contagem dos sete anos.

A busca do conhecimento transforma-se, então, numa luta contra o tempo, invertendo completamente sua noção original, quebrando a idéia de 
que o tempo é a soma das experiências de vida. O terreiro passa a ser visto como uma escola ocidental, que estipula prazos e, ao final deles, outorga títulos e diplomas que atribuem direitos no mercado profissional. O lugar do tempo africano, o tempo do mito, é tomado pelo tempo do relógio.

\section{$\mathbf{I X}$}

Velhos iniciados contam que nos idos e saudosos tempos do candomblé antigo o recolhimento à clausura, onde se processa a iniciação, não tinha duração pré-determinada. O filho-de-santo ficava recolhido no terreiro o tempo necessário à sua aprendizagem de sacerdote e à realização de todas as atividades que os ritos de uma feitura de orixá envolvem. Podia ficar meses, muitos meses, isolado do mundo, totalmente mergulhado na sua iniciação. Isso ficou para trás. Hoje, cada iniciação, que se faz num período que não soma os dias de um mês, tem de ser cuidadosamente planejada, de modo a encaixar os dias de recolhimento do filho-de-santo nas suas férias de trabalho ou nos momentos vagos deixados pelos compromissos da vida secular. O tempo da iniciação passa a ser regulado pelo tempo do mercado de trabalho. O tempo africano do terreiro é vencido pelo tempo da sociedade capitalista.

Nesta nossa sociedade do tempo irreversível, cada vez mais as imagens e referências do tempo circular vão se perdendo: o relógio analógico, com seus ponteiros sempre dando a volta para retornarem ao ponto zero, são substituídos pelo relógio digital; os supermercados 24 horas e outros negócios essenciais ao consumo na vida cotidiana não fecham para descanso; os canais de televisão ficam no ar noite e dia; trabalha-se em qualquer período; a internet mantém ininterrupto o acesso aos arquivos de informação dos computadores ligados na rede mundial; até o amor se faz a qualquer hora nos motéis full-time; a eletricidade há muito acabou com a escuridão e fez da noite, dia; a engenharia dos transgênicos nos faz sonhar com uma natureza transformada a cada colheita. Se até na natureza o tempo cíclico vai perdendo importância, que dirá na vida do terreiro.
Os velhos do candomblé falam do passado como um tempo perdido, que já não se repete, vencido por um presente em que impera a pressa, o gosto pela novidade, a falta de respeito para com as caras tradições e, sobretudo, o descaso para com os mais velhos. Dizem que "o candomblé hoje vive de comércio, é pura exibição", reclamam que "uns querem ser mais que os outros", falam que "os que mal saíram das fraldas, que não sabem nada, já empinam a cabeça para os antigos", lamentam que "os velhos babás e as velhas iás não tem mais voz em nada", asseveram que "os jovens o que querem é sugar os seus mais velhos e depois chutar seu traseiro e buscar outro lugar onde podem mandar à vontade". Falam com saudade daquele mundo ideal que ficou para trás e gostam sempre de frisar que "no meu tempo não era assim", repetindo que "hoje ninguém mais tem humildade, querendo saber mais do que os antigos, essas crianças presunçosas, esses jovens cheios de vento". Seu discurso triste revela certamente muito de nostalgia da juventude, mas é também o testemunho verdadeiro de perdas efetivas.

O presente agora se descortina como ruptura, descontinuidade. O passado não explica mais, nem se completa no presente. Os mitos vão sendo esquecidos, os odus simplificados, os deuses ganham ares mais condizentes com a modernidade. Os jovens acusam os mais velhos de levarem para o túmulo segredos iniciáticos que não transmitem para ninguém, enfraquecendo os mistérios da religião e sua força, o axé, mas de fato não se importam muito com isso. Acreditam menos na existência dos segredos do que os mais velhos diziam acreditar. Aprenderam que a tradição é e pode ser construída a cada instante, pois a lei-dosanto, que ordena as tradições do candomblé, não tem mais do que um século de vida, nem uma única versão, e está sempre mudando. E levam adiante sua religião, pensando no futuro.

\section{$\mathbf{X}$}

Para o Ocidente, o futuro é a grande incógnita a ser decifrada, controlada, um tempo a ser planejado para melhor ser usufruído. A esperança 
sempre se deposita num tempo vindouro para o qual são pensadas as grandes realizações que devem ser introduzidas em prol da felicidade humana. Investe-se no futuro. Olha-se para o passado procurando os erros cometidos e que devem ser evitados no presente para garantir um futuro melhor. A história ensina como agir com sabedoria e responsabilidade em face do devir. Um emblemático mote de Karl Marx diz que na história nada se repete, a não ser como farsa. Para o africano tradicional é o contrário: a repetição é o almejado, o certo, o inquestionável. O novo, o inesperado, o que não vem do passado, é o falso, o perigoso, o indesejável.

O candomblé dos dias de hoje está posto entre esses dois conceitos opostos de tempo. Um e outro remetem a concepções diversas de aprendizado, saber e autoridade. Levam a noções divergentes sobre a vida e a morte, a reencarnação e a divinização. Nesse embate, a religião muda, adapta-se, encontra novas fórmulas e adota novas linguagens. Os orixás ganham novos territórios, conquistam adeptos nas mais diferentes classes sociais, origens raciais e regiões deste e outros países. O que a realidade social das religiões no Brasil tem mostrado é que a religião dos orixás cresce e prospera (Pierucci e Prandi, 1996). Sobretudo se transforma, cada vez mais brasileira, cada vez menos africana. Mesmo o movimento de africanização, que procura desfazer o sincretismo com o catolicismo e recuperar muitos elementos africanos de caráter doutrinário ou ritualístico perdidos na diáspora, não pode fazer a religião dos orixás no Brasil retornar a conceitos que já se mostraram incompatíveis com os da civilização contemporânea. O tempo africano perde sua grandeza, vai se apagando. Permanece, contudo, nas pequenas coisas, fragmentado, manifestando-se mais como ordenador de um modo peculiar de organizar o cotidiano característico de uma religião que se mostra exótica, extravagante e enigmática.

E pouco a pouco o povo-de-santo acerta seus relógios. Sabe que o candomblé deixou de ser uma religião exclusiva dos descendentes de escravos africanos - uma pequena África fora da sociedade, o terreiro como sucedâneo da perdida cidade africana, como ainda o encontrou Roger
Bastide quase meio século atrás (Bastide, 1971, pp. 517-518) - para se tornar uma religião para todos, disposta a competir com os demais credos do país no largo e aberto mercado religioso. Uma instituição dos tempos atuais em um processo de mudança que reformula a tradição e elege novas referências, para o bem e para o mal. O tempo é tempo de mudar.

\section{BIBLIOGRAFIA}

BABATUNDE, Emmanuel D. (1992), A critical study of bini and yoruba value systems of Nigeria in change: culture, religion and the self. Lewinston, UK, The Edwin Mellen Press.

BASTIDE, Roger (1971), As religiões africanas no Brasil. São Paulo, Pioneira.

(1978), O candomblé da Babia: rito nagô. 3a. ed. São Paulo, Nacional.

DREWL, Margaret Thompson (1992), Yoruba ritual: performers, play, agency. Bloomington, Indiana University Press.

ELLIS, A. B. (1974), The yoruba-speaking peoples of the slave coast of West Africa. 2. ed. Londres, Pilgrim.

FABIAN, Johannes (1983), Time and the other: how anthropology makes it object. Nova York, Columbia University Press.

JOHNSON, Samuel (1921), The history of the yorubas. Lagos, Nigéria, CSS Bookshops.

LANDES, Ruth (1947), The city of women. Nova York, Macmillan. Edição brasileira (1967): A cidade das mulberes. Rio de Janeiro, Civilização Brasileira.

LIMA, Vivaldo da Costa (1984), "Nações-de-candomblé", in LIMA, Vivaldo da Costa (org.), Encontro de nações de candomblé. Salvador, Centro de Estudos Afro-Asiáticos da UFBa e Ianamá.

MBITI, John S. (1990), African religions and philosophy. 2. ed. Ibadan, Nigeria, Heinemann Educational Books. 
MBON, Friday M. (1991), "African traditional socio-religious ethics and national development: the nigerian case, in OLUPONA, Jacob K. (ed.), African traditional religions in contemporary society, St. Paul, Minnesota, Paragon House.

ODUYOYE, Modupe (1996), Words \& meaning in yoruba religion. Londres, Karnak House.

PIERUCCI, Antônio Flávio e PRANDI, Reginaldo (1996), A realidade social das religiões no Brasil. São Paulo, Hucitec.

PRANDI, Reginaldo (1991), Os candomblés de São Paulo: a velha magia na metrópole nova. São Paulo, Hucitec.

(1996), Herdeiras do axé: sociologia das religiões afro-brasileiras. São Paulo, Hucitec.

(1999), "Conceitos de vida e morte no ritual da axexê: tradição e tendências recentes dos ritos funerários no candomblé", in MARTINS, Cléo e LODY, Raul (orgs.), Faraimará, o caçador traz alegria: Mãe Stella, 60 anos de iniciação. Rio de Janeiro, Pallas.

(2000a), "Religião, biografia, conversão". Tempo e Presença. Rio de Janeiro, 310: 34-44, março-abril.

. (2000b), "African gods in contemporary Brazil". International Sociology, Londres, dezembro, 15 (4): 641-663, dezembro.

(2000c), "Hipertrofia ritual das religiões afro-brasileiras". Novos Estudos Cebrap, São Paulo, 56: 77-88, março.

. (20001), Mitologia dos orixás. São Paulo, Companhia das Letras.

PRIGOGINE, Ilya (1991), O nascimento do tempo. Lisboa, Edições 70.

SILVEIRA, Renato da (2000), "Jeje-nagô, iorubátapá, aon efan e ijexá: processo de constituição do candomblé da Barroquinha, 1764-1851". Revista Cultura Vozes, Petrópolis, 94 (6):80-101.
SOYINKA, Wole (1995), Myth, literature and the African world. Cambridge, Cambridge University Press, 1995. Primeira edição: 1976. 


\section{O CANDOMBLÉ E O TEMPO}

Reginaldo Prandi

\section{Palavras-chave}

Tempo e religião; Tempo e hierarquia religiosa; Tempo e iniciação; Tempo nas religiões afro-brasileiras.

Procura-se mostrar como concepções de tempo, aprendizagem e saber, próprias do candomblé, são constitutivas da cultura africana de povos que instituíram no Brasil a religião dos orixás. A idéia de vida e morte, nascimento e reencarnação, assim como o culto aos antepassados e aos orixás, tal como concebidos em solo africano, reproduziramse no Brasil em conformidade com aquelas concepções. Com a transformação do candomblé em religião não mais restrita a afro-descendentes e sua propagação por todo o país, congregando agora adeptos inseridos num mundo de trabalho e de aprendizado controlado pelo tempo capitalista, as concepções ocidentais vão minando os conceitos africanos de tempo e, especialmente, de saber, alterando-se princípios iniciáticos e de constituição da autoridade, da hierarquia e do poder religioso nos terreiros, com mudanças profundas na religião.

\section{CANDOMBLÉ AND THE TIME}

\author{
Reginaldo Prandi
}

\section{Keywords}

Time and religion; Time and religious hierarchy; Time and initiation; Time in Afro-Brazilian religions.

The article tries to show how conceptions of time, learning and knowledge, typical aspects of Candomblé, are a constituent part of African culture and people that instituted the orixás religion in Brazil . The idea of life and death, birth and reincarnation, as well as the cult to the ancestors and to the orixás, as conceived in African soil, was reproduced in Brazil in conformity with those conceptions. With the transformation of Candomblé in a religion not only restricted to afro-descendants and its propagation around the country, congregating followers inserted in the world of work and of controlled learning, based on the capitalist notion of time, the Western conceptions undermine the African concepts of time, especially those concerning knowledge, changing the initiation practices and the constitution of authority, hierarchy and the religious power in the terreiros (yards), provoking deep changes in the religion.

\section{LE CANDOMBLÉ ET LE TEMPS}

\author{
Reginaldo Prandi
}

\section{Mots-clés}

Temps et religion; Temps et hiérarchie religieuse; Temps et initiation; Temps dans les religions afro-brésiliennes.

Par cette étude, l'auteur cherche à démontrer de quelle manière les conceptions de temps, d'apprentissage et de savoir, propres au candomblé, sont des éléments constitutifs de la culture africaine, de peuples qui ont institué, au Brésil, la religion des Orishas. L'idée de vie et de mort, de naissance et de réincarnation, ainsi que le culte aux ancêtres et aux Orishas, tel que conçu en sol africain, se sont reproduits au Brésil suivant ces conceptions. Avec la transformation du candomblé en une religion qui n'est plus restreinte aux seuls descendants africains, et sa propagation dans l'ensemble du pays, réunissant des adeptes insérés dans un monde de travail et d'apprentissage contrôlé par le temps capitaliste, les conceptions occidentales minent peu à peu les concepts africains de temps et, particulièrement, de savoir, altérant ainsi des principes initiatiques et de constitution de l'autorité, de la hiérarchie et du pouvoir religieux dans les terreiros (temples d'influence Nago), avec de profonds changements dans la religion. 